\title{
УПРОВАДЖЕННЯ АЛГОРИТМІЗАЦІЇ В МЕДСЕСТРИНСЬКУ ОСВІТУ
}

\author{
Н. В. Попович \\ Міжгірський медичний коледж \\ ДВНЗ «Тернопільський державний медичний університет \\ імені І. Я. Горбачевського МОЗ України»
}

У статті проаналізовано поняття «алгоритм» і «алгоритмізація навчання», доцільність застосування даної педагогічної технології при підготовці медичної сестри.

\section{IMPLEMENTATION OF ALGORITHMIZATION IN NURSES’ EDUCATION}

\author{
N. V. Popovych \\ Mizhhirsk Medical College \\ I. Horbachevsky Ternopil State Medical University
}

The article analyzes the concept of «algorithm» and «algorithmic learning», the feasibility of using this pedagogical technology in the preparation of a nurse.

Вступ. Модернізація медсестринської освіти в Україні зумовлена необхідністю покращення здоров'я української нації, якісного рівня їі життєдіяльності. Відомо, що за оцінками експертів Всесвітньої організації охорони здоров'я, медсестринська освіта станом на 1990 р. на теренах України значно відставала від країн Європи. Не відбулося суттєвих змін у медсестринській освіті і за період незалежності України [1, 2].

Рівнем підготовки медсестринських кадрів не повністю задоволені і лікувально-профілактичні заклади нашої країни. Насамперед є зауваження до практичної професійної підготовки медичної сестри. Про нагальність вирішення цієї проблеми свідчать матеріали науково-практичних медсестринських конференцій, опитування проведені серед керівного складу медсестринських кадрів лікарень тощо [3]. 3 огляду на це, головним завданням професійної медсестринської освіти $є$ підготовка кваліфікованих конкурентоспроможних кадрів із високим рівнем сформованості професійних знань, навичок і вмінь, творчого мислення, кращих людських якостей, національної свідомості [1-3].

Основна частина. За умов науково-технічного прогресу постають певні вимоги до якості професійної

() Н. В. Попович, 2017 підготовки медичних сестер: вільне володіння фундаментальними і спеціальними знаннями та вміннями у питаннях комплексного догляду за пацієнтами; здатність до аналітичного мислення і творчої діяльності, що пов'язана з функціональними обов'язками медичної сестри; здатність до самовдосконалення і самонавчання тощо.

Аналіз сучасного стану медсестринства в Україні показав, що модернізація медсестринської освіти має здійснюватися за такими напрямками: державнозаконодавчий, науково-методичний, навчальноорганізаційний [4, 5].

Значні зміни у модернізації медичної освіти сьогодні пов'язані також із приєднанням України до країн-учасниць Болонської декларації. Основна мета країн, які підписали Болонську декларацію, зводиться до підвищення якості та стандартизації освіти в усьому європейському просторі відповідно до єдиних вимог, критеріїв і стандартів освіти. Покращення підготовки медичних сестер дозволяє розширити міжнародну конкурентоспроможність медичної освіти України, отримати можливості працевлаштування наших випускників і за межами держави.

У незалежній Україні стало можливим вивчення міжнародного досвіду, що викликало необхідність 
реформування медсестринської освіти до рівня міжнародних стандартів. Це потребує зусиль у таких напрямках: по-перше, удосконалення змісту системи знань з метою підвищення рівня професійних умінь для кожної спеціальності; по-друге, застосування як у теоретичному, так і в практичному навчанні спеціальних методичних прийомів, що спрямовані на використання отриманих знань у практичній підготовці [6, 7]. Ідеться про використання виробничої навчальної гри, вирішення виробничих і ситуативних завдань, створення орієнтирів для зіставлення знань студентів у виробничих ситуаціях, відпрацювання практичних навичок і вмінь на високоякісних тренажерах, застосування методу аналогій та ін.; по-третє, вдосконалення професійної спрямованості викладання спеціальних предметів, упровадження в навчальний процес досконалих робочих програм і навчальних планів, якісних теоретичних і практичних підручників, на основі яких повинен бути розроблений необхідний навчально-методичний матеріал: інструкції, комплекси методичного забезпечення, професійні алгоритми, міжпредметні комплексні завдання, карточкизавдання та ін.; по-четверте, використання технічних засобів навчання (комп'ютерні технології, навчальні відеофільми, фотознімки, малюнки, схеми тощо) [6-8].

Одним із загальних методів навчання, який дозволяє оптимізувати підготовку майбутньої медичної сестри, є алгоритмізація навчально-виховного процесу. Однак, означена проблема ще не була предметом спеціального дослідження в підготовці медичних сестер. Всебічного дослідження потребують, зокрема, такі аспекти: теоретичне обґрунтування необхідності алгоритмізації при підготовці медсестри; розроблення і широке впровадження в навчальний процес алгоритмів різного рівня складності й узагальнення - простих, складних, комбінованих, комплексних, загальних тощо; розроблення і впровадження різних моделей алгоритмізації теоретичної і практичної підготовки; гармонійне поєднання загальноприйнятих форм i методів навчання з алгоритмічними методиками.

Необхідність упровадження широкої алгоритмізації в медсестринську освіту підтверджується й резолюцією конференції з проблем вищої освіти під егідою ЮНЕСКО, що відбулася в Парижі 5-9 жовтня 1998 р. Із матеріалів цієї конференції випливає, що тенденції сучасної освіти спрямовані не на об'єм, а на фундаментальність засвоєння знань, навичок і вмінь, на вироблення властивості сприймати, розуміти й засвоювати прискорений потік нової інформації. Алго- ритмічні технології навчання дають змогу виконати поставлені завдання.

Вивчення психолого-педагогічної літератури дало можливість стверджувати, що алгоритмізація навчання майбутніх медичних сестер у сучасних умовах сприяє ефективному та раціональному вирішенню важливих завдань, що стоять на шляху вдосконалення процесу підготовки майбутньої медичної сестри у контексті положень Болонської декларації, правової і нормативної бази системи охорони здоров'я, професійної і медсестринської освіти.

Аналіз понять «алгоритм» і «алгоритмізація навчання» дозволили обґрунтувати доцільність застосування даної педагогічної технології підготовки медичної сестри. Різностороннє осмислення проблеми алгоритмізації дало змогу: створити власну класифікацію алгоритмів практичної діяльності відповідно до складності й узагальнення відповідного матеріалу; впровадити триетапну модель алгоритмізації практичної підготовки майбутньої медичної сестри, а саме:

- первинне засвоєння базових практичних навичок за допомогою алгоритмів їх виконання;

- поглиблене засвоєння практичних дій до рівня умінь за допомогою алгоритмічних критеріїв їх відпрацювання;

- завершення формування професійних умінь за допомогою алгоритмічних критеріїв вирішення і практичного засвоєння навчально-виробничих задач і завдань.

Наукова новизна і теоретичне значення дослідження полягає в тому, що: вперше обґрунтовано структуру професійних умінь медичної сестри; розроблено і обґрунтовано технологію та зміст формування професійних умінь медичної сестри засобами алгоритмізації; подальшого розвитку набули форми і методи професійної підготовки майбутньої медичної сестри у вищих медичних навчальних закладах I-II рівнів акредитації; уточнено теоретичний зміст понять «професійні знання», «професійні навички», «професійні уміння»; теоретично обґрунтовано доцільність формування професійних умінь у майбутніх медичних сестер засобами алгоритмізації.

Розроблено технологію побудови алгоритмів різного ступеня складності й узагальнення матеріалу, а саме: лінійних алгоритмів для засвоєння простих практичних навичок, в основі яких лежить поділ складної для одномоментного виконання дії на ряд більш простих і зрозумілих послідовних компонентів, з наступним їх об'єднанням у загальну структуру; 
лінійно-розгалужених алгоритмів для виконання складних практичних навичок, структура яких включає загальну послідовність виконання складної дії і алгоритми окремих простих навичок; алгоритмів відпрацювання простих і складних практичних дій до рівня професійних умінь, шляхом визначення i детальної розробки алгоритмічних критеріїв, їх вивчення, відпрацювання і оцінювання, в структурі якого послідовність виконання дії (алгоритм виконання дії на рівні навички) є лише одним із критеріїв; алгоритмічних критеріїв (еталонів) розв'язування типових і ситуаційних навчальних задач і завдань 3 наступним відпрацюванням комбінованих і комплексних загальних алгоритмів практичної діяльності на рівні професійних умінь.

Зміст формування професійних вмінь у майбутніх медичних сестер засобами алгоритмізації визначається на основі розробки алгоритмів послідовного виконання розумових і відповідних до них практичних дій з метою вирішення поставлених задач і завдань. Визначено, що за умов алгоритмічного підходу до навчання, засвоєння знань, навичок і вмінь студентами відбувається шляхом послідовного засвоєння взаємопов'язаних навчальних дій і операцій, а саме: отримання чітких і глибоких професійних знань; теоретичне вивчення і практичне відпрацювання закладених в освітньо-кваліфікаційній характеристиці випускника простих навичок і вмінь на основі відповідних алгоритмів; відпрацювання складних комбінованих і комплексних алгоритмів діяльності на основі раніше засвоєних простих алгоритмів; поступова

\section{СПИСОК ЛІТЕРАТУРИ}

1. Маркович О. В. Загальні принципи формування професійних знань, навичок, умінь: особливості формування професійних умінь в умовах медичного коледжу : методичні рекомендації / О. В. Маркович. - Рівне : Рівненський державний базовий медичний коледж. - 2006. 43 с. - 1,7 авт. арк.

2. Будапештсько-Віденська декларація про створення європейського простору вищої освіти - 12 березня 2010 р.

3. Ковальчук Л. Я. Впровадження новітніх методик i систем навчального процесу в Тернопільському державному медичному університеті імені І. Я. Горбачевського / Л. Я. Ковальчук // Медична освіта. - 2009. - № 2. - С. 10-14. відмова від алгоритмічного поетапного виконання дій з використанням інструктивної підтримки і перехід на автоматизовану діяльність; алгоритмічне вирішення і практичне виконання поставлених типових і навчально-виробничих завдань; складання власних алгоритмів виконання професійних дій з елементами творчості відповідно до особливостей психічної діяльності та фізіологічних властивостей свого організму.

Доведено, що навчальна, самостійна, індивідуальна та дослідницька робота медичної сестри буде більш ефективною, якщо у визначенні форм і методів традиційного навчання враховувати позитивні властивості алгоритмізації. Алгоритмічні технології найбільш органічно поєднуються з методами первинного вивчення і відпрацювання раніше невідомих навичок і вмінь та контролю за їх виконанням, а також з проблемними, імітаційними та ігровими методами практичної підготовки. Доведено, що алгоритмізація практичної підготовки медсестри $є$ найефективнішою при достатньому забезпеченні навчального процесу наочними засобами, насамперед сучасними інформаційними технологіями і функціональними тренажерами.

Висновки. Виходячи з того, що майбутня професійна діяльність медичної сестри пов'язана із засвоєнням значної кількості практичних умінь і навичок, а кожна її дія має виконуватися чітко і безпомилково (оскільки від цього залежить ефективність лікування, здоров'я, а іноді й життя пацієнта), алгоритмізацію слід вважати досить вдалою педагогічною технологією навчальнопрофесійної підготовки.

4. Алексюк А. М. Взаємодія форм організації методів навчання / А. М. Алексюк, В. К. Дяченко // Радянська школа. - 1983. - № 7. - С. 8-14.

5. Алексюк А. М. Педагогіка вищої освіти України. Історія, теорія / А. М. Алексюк. - К. : Либідь, 1998. - 56 с.

6. Ансофф И. Стратегическое управление ; сокр. пер. с англ. / И. Ансофф. - М. : Экономика, 1989. - 303 с.

7. Архангельский С. И. Лекции и теории обучения в высшей школе / С. И. Архангельский. - М. : Высшая школа, 1974. - 384 с.

8. Баєва О. В. Менеджмент у галузі охорони здоров'я / О. В. Баєва. - К. : Центр учбової літератури, 2008. - 640 с. 